\title{
STATE LIABILITY FOR VIOLATION OF CONSTITUTIONAL RIGHTS AGAINST INDIGENOUS PEOPLE IN FREEDOM OF RELIGION AND BELIEF
}

\author{
Zaka Firma Aditya, S.H. and Sholahuddin Al-Fatih, S.H. ${ }^{1}$ \\ ${ }^{1}$ Magister of Law, University of Airlangga, \\ Email: zaka.aditya@gmail.com Sholahuddin.alfath@gmail.com
}

Submitted : 04-01-2017 | Accepted: 20-2-2017

\begin{abstract}
The government is perceived as the main perpetrator on violations of freedom of religion and belief in Indonesia. As the state organizer, the government frequently issues discriminatory regulations and policies and tend to cause intolerance to minority religions and beliefs, particularly to indigenous peoples. While freedom of religion or belief is a constitutional rights that cannot be reduced and is guaranteed universally in constitution and laws, the law provides limitation that causes ambiguity in the fulfillment of the rights of religion and belief. In addition, the government mindset still adheres to the term of "official religion" and "non-official religion" in any policy-making, causing adherents of minority religions and beliefs to be considered as cultural heritage to be preserved. This creates injustice, discrimination, intimidation and intolerance in rights fulfillment in state and society life.

This paper discusses the existence of the guarantee of freedom of religion and belief for indigenous people and state liability for violations of freedom of religion and belief. This research used normative juridical method with statute approach and conceptual approach.
\end{abstract}

Keywords: guarantee, religion, belief, indigenous peoples, human rights, liability

\section{INTRODUCTION}

Protection of the constitutional rights of Indonesian citizens to religious freedom is far from expectations. National Commission on Human Rights (Komnas HAM) reported increase on violations of religious freedom cases by 74 reports in 2014 to 87 reports in 2015 with 93 violations of freedom of religion and belief $^{1}$. The similar report was received by The Wahid Institute during 2015 reaching 190 cases and 249 actions. This number was 23 percent higher than that of 2014 by 158 cases reported and 187 violations of freedom of religion and belief ${ }^{2}$. The highest case of violation was prohibition and destruction of places of worship and the prohibition of obstructionism and harassment of religious activity as well as

1 Cited from http://www.voaindonesia.com/a/pelanggaran-kebebasan-beragama-meningkat-/3203566.html accessed on 20 August 2016 at 20.10

2 Ibid. See also The Wahid Institue, Laporan Tahunan Kebebasan Beragama/Berkeyakinan dan Intoleransi Tahun 2014, Jakarta, 2014, 21 
the omission of violence. More ironically, local government as obligation stakeholder in protecting the rights of the community was the actor frequently issued discriminatory policies which sometimes lead to violence in the community.

In fact, freedom of religion and belief has been fully guaranteed in the Constitution and the various laws and regulations and other legal instruments. In Section 28E of paragraph (1) and (2) the Constitution specifically reflects the basic values of the Deity of the Almighty in a more detailed form of freedom of religion and to worship according to religion and belief respectively ${ }^{3}$. This article is then reinforced in the provision of Article 29 paragraph (1) of the 1945 Constitution stating that " The State shall be based upon the belief in the One and Only God", while paragraph (2) mentioned; " The State guarantees all persons the freedom of worship, each according to his/her own religion or belief." The consequence is the guarantee in the constitution, making the right of every citizen to perform the teachings of religion, belief and ritual worship has become a constitutional right. As a constitutional right, the state has an

3 Ria Asmi Carsi, 'Inkonsistensi Perlindungan Hukum Bagi Penghayat Kepercayaan Terhadap Tuhan Yang Maha Esa', n.3 2013, Jurnal Keadilan Sosial, 39-40.

4 Lukman Hakim Saefuddin, 'Indonesia adalah Negara Agamis: Merumuskan Relasi Agama dan obligation to guarantee, protect and fulfill the rights, to promote harmony, peace, and harmony within the frame of the life of society, nation and State. ${ }^{4}$

As a pluralistic country, religion and beliefs held by the people of Indonesia should be able to prove that a plural society has coexisted in difference. The society should get along in social mobility, economy, and religion in everyday life. In some areas, the religious differences occur in one family, bound by customs. In addition, religions in Indonesia reflect the plurality of faith and belief in God. Islam, Protestant, Catholic, Hindu, Buddhist, and Confucian frequently referred to as the state religion as they receive many facilities particularly by the state. While the six religions are gaining the attention of the state, the adherents of other religions such as Baha'i, Sinto, Jewish, kejawen, Kahuringan and indigenous religious beliefs inherited by the ancestors are free to be embraced and believed by the society. In other words, religious values, customs, and culture are manifestation of view of life and society spiritual ethos as the crystallization of learning from interaction and internalization of the values of human

\footnotetext{
Negara dalam Perspektif Pancasila', (Paper presented at the "Kongres Pancasila" held by Gadjah Mada University, Yogyakarta and The Constitutional Court of the Republic of Indonesia, in Yogyakarta, 30 May-1 June 2009), 4.
} 
beings on the environment from generation to generation.

In its development, however, the government no longer recognizes beliefs as a stand-alone entity beyond religion, yet as merely culture. Furthermore, the government invited, even urged beliefs adherents to return to the main religions ${ }^{5}$. The government's call leads to newly more crucial problems. The adherents of beliefs rejected to return to the six main religions recognized by the government, namely Islam, Catholic, Christian, Buddhist, Hindu and Confucian. They believed that tit is their religion that deserves to be called as the major religion in Indonesia. The six major religions recognized by the government, according to them, is nothing but imported religion, not the original religion of the archipelago, their religion has long existed in the country even before Indonesia was established ${ }^{6}$.

The series of intolerance and discrimination acts indicate that diversity portrait has suffered deprivation from plurality roots. Despite the progress

5 Siti Musdah Mulia, 'Menuju Kebebasan Beragama', (Paper presented in a Seminar and Workshop of Komnas HAM on the theme of Freedom of Religion and Belief in Indonesia, Palu, 11-12 September 2006), 51

${ }^{6}$ ibid

7 Siti Musdah Mulia, 'Potret Kebebasan dan Berkeyakinan di Era Reformasi', (Paper presented at the National Workshop on the theme Human Rights Commission of Human Rights
Indonesia has made after reformation era on religion issues particularly in term of setting, there are still problems to be solved from regulatory issues to increasing violence. It indicates that issue of religious freedom is not only a state problem and it is certain that there is no single solution to solve the complex problem ${ }^{7}$. Mahfud $\mathrm{MD}^{8}$ confirmed that the shift of authoritarian regime to democracy is obviously good news for freedom of religion, belief, expression and association. However, its implementation has been problematic. As the government was formed through democratic mechanisms, it is powerless to reduce the intensity of religious freedom issue. In fact, Indonesia is accused as perpetrator of religious discrimination, particularly against religious minorities, groups, and marginalized indigenous people.

Comparing the state diversity and the reality, there are three tendencies frequently faced by plural society including; (1) develop potential chronic conflicts in relations between groups, (2) Actors of conflict perceive it as an all-out war (3) the

Enforcement in the 10 Years of Reform, in Borobudur Hotel, Jakarta, 8-11 Juli 2008), 32.

8 Mahfud MD, 'Kebebasan Beragama Dalam Perspektif Konstitusi', (Paper presented at the Conference of Religious Leaders of ICCPR: Affirming Religious Freedom in Indonesia, Demanding Commitment of President and Vice President-elect, held by Indonesian Conference on Religion and Peace (ICRP) Monday, 5 October 2009 Jakarta), 1. 
process of social integration occurs through domination of one group by another group. Potential of conflicts in plural society cannot be denied. In the past, religious harmony should be paid very expensively with the explosion of sectarian violence in a number of areas. Therefore, the greatest challenge for a plural society is the fragility of the common bonds as a result of differences in religion (faith and trust) that easily trigger inter-religious conflict if not properly managed. Religious conflict has always been a very serious challenge for the pluralistic Indonesia. Plus, the absence of official recognition of the minority religions and beliefs cause believers to experience social exclusion from community stigmatization.

This is evidence from the number of Government and Parliament/DPRD member who consider believers groups and indigenous peoples as underdeveloped community group and as an improperly godless community group, even heretical or have deviant beliefs. Various groups of people also consider that members of minority religious groups need to be encouraged to adopt official religions.

\section{LEGAL MATERIALS AND METHOD}

This paper uses juridical-normative method. The approach used in this Paper are statute approach and conceptual approach. Statue approach was carried out by examining all acts and regulations related to religious freedom both national laws and international ratification. Conceptual approach was formed moved from views, doctrines and concepts of law developed in the science of law. The legal materials used in this research were primary and secondary laws. Primary legal materials are in the form of laws and court decisions. Secondary legal materials are in the form of legal books, law papers and journals.

\section{RESULT AND DISCUSSION}

The Existence Of Freedom Of Religion And Belief Of Indigenous People

A. Constitutional Guarantees of Freedom of Religion and Belief in Indonesia and International Covenants

Constitutional protections of citizens in running various activities in religion and beliefs are contained in various acts and regulations both in national and international levels. In Indonesia's constitution, the philosophy of religions and beliefs recognition had first existed before the UDHR 1948, ie on the basis of Pancasila (philosophical foundation of the Indonesian state) in the first principle "Belief in the one 
and only God". The opening of the 1945 Constitution also stated "By the grace of God Almighty..." implying the recognition of the Indonesian to the power of God, that Indonesia recognizes the establishment of the nation is due to the grace of God. This, addition to embracing the rule of law, indicate that Indonesian also embrace the sovereignty of God. The implication is that the state, as a representative of God, should be able to protect, respect and fulfill its citizens to worship God.

Pancasila, the philosophical basis of the state has also guided its people to religion (the $1^{\text {st }}$ principle), by upholding humanitarianism ( $2^{\text {nd }}$ principle), and unity ( $3^{\text {rd }}$ principle). The problems faced the nation are settled by deliberation $\left(4^{\text {th }}\right.$ principle) and not by the logic of the majority. There is no extreme social inequality between rich and poor without ( $5^{\text {th }}$ principle). Indonesian dream rooted in collectivism and individualism, Pancasila idealism is not individual welfare yet prosperous society. Social justice is the estuary of the four other ${ }^{9}$ precepts. As the

\footnotetext{
${ }^{9}$ M. Amin Abdullah, 'Kebebasan Beragama Atau Berkeyakinan Dalam Perspektif Kemanusiaan Universal, Agama-Agama Dan Keindonesiaan' (Papers Presented in forum Advanced Human Rights Training for Lecturers of Law and Human Rights by the Centre for Human Rights Studies, Islamic University of Indonesia (PUSHAM UII) in Yogyakarta in cooperation with Norwegian Centre for Human Rights (NCHR) University of Oslo Norway, Djogjakarta Plaza Hotel, 10 June 2011), 14-15
}

juridical consequences of this recognition, the state has duty to respect, protect and fulfill the rights of its citizens in performing religion or belief.

A series of state guarantees on freedom of religion and belief are mentioned in Article 28E paragraph (1) and (2), Article 28 paragraph (1), Article 28J paragraph (2) and Article 29 paragraph (1) and (2) of the 1945 Constitution. Article 28E (1) and (2) generally reflects the basic values of Belief in the one and only God in a more detailed form of freedom of religion and to worship according to religion or belief respectively. While Article 29 paragraph (2) sets up a specific thing with the word " The State guarantees all persons the freedom of worship, each according to his/her own religion or belief"10. This means that the state has an obligation to guarantee and meet its citizens in religious worship and belief. In addition, with the presence of state guarantees on religion and beliefs of citizens, the freedom of religion and belief is automatically a constitutional

10 Our constitution recognizes and specifies two words, which appears to overlap each other: "kemerdekaan (independence)" and "kebebasan (freedom)". For example, in Article 28, first paragraph 1 or Article 29 paragraph (2). The word "free" or "freedom" can be found in Article 28E (1) and (2). With nearly similar editorial, the word "independence" in section $28 \mathrm{I}$ of the 1945 Constitution was changed to "freedom" in article 4 of the Human Rights Law No. 39 of 1999 on Human Rights. See The Wahid Institute (2014), above n.3, 5 . 
right of citizens that should not be reduced in any form.

The state's guarantees to citizens' religious beliefs also exist in various acts including Law No. 39 of 1999 on Human Rights, Article 22 paragraph (1) mentioned; "Everyone is free to embrace their religion and to worship according to his religion and belief". Article 22 paragraph (2) mentioned; "The state guarantees freedom of every person to embrace their religion and to worship according to his religion and belief".

In 2005, the Government of Indonesia ratified ICCPR (1966) which is then adopted in Act No. 12 Year 2005 and the ICESCR (1966) adopted in Act No. 11 Year 2005. In each of the ratification of the Covenant, Indonesian government did not do anything except making a declaration regarding the right to self-determination (Article 1). With the second ratification of the Covenant, Indonesia is bound as a State Party to the Treaty of human rights and must adhere to implement the contents of both the Covenant and to submit periodic reports to the UN Human Rights Treaty Body ${ }^{11}$. Act No. 12 Year 2005 concerning the Ratification of the International Covenant on Civil and Political Rights

${ }^{11}$ Komnas HAM, Upaya Negara Menjamin HakHak Kelompok Minoritas di Indonesia : Sebuah Laporan Awal, Komisi Nasional dan Hak Asasi Manusia, Jakarta, 2016, 18.
(ICCPR) Article 18 paragraph (1), stated: "Everyone has the right to freedom of thought, conscience and religion. This right includes freedom to adopt or accept a religion or belief of his choice, and freedom, either individually or jointly with others, and in public place or enclosed, to practice a religion or belief in worship activities, observance, practice and teaching." Article 18 paragraph (2) mentioned; "No one should be forced to interfere with his freedom to adopt or accept a religion or belief of his choice". The ratification of this convention means that Indonesian government has insisted that the conception of human rights in Indonesia has been universal, and the ratification has legally binding ${ }^{12}$.

Act No. 7 year 2012 on Social Conflict Management also gives attention to the possible emergence of issues related to religion. This acts sees religion issues as one of the potential conflicts through enmity between religious communities and/or the Inter-religions. However, this acts confirms that the handling of the conflict coming from religious matters

\footnotetext{
${ }^{12}$ Shanti Rachmadsyah in M. Syafi' ie, 'Ambiguitas Hak Kebebasan Beragama di Indonesia dan Posisinya Pasca Putusan Mahkamah Konstitusi', V.8 n.5 October 2011, constitution journal, 683.
} 
should reflect the principle of human rights ${ }^{13}$.

Freedom of religion and belief is also regulated in the UDHR adopted in 1948 as one of the forms of human rights, in Article 18 stating; "Everyone has the right to freedom of thought, conscience and religion; in this case, including change religion or belief ..." It also covers series of articles of the 1981 Universal Declaration on the Elimination of Intolerance and Discrimination Based on Religion. Article 1 (2) states: "no one can be subjected to coercion which would reduce the freedom to follow a religion or belief according to his choice". Article 6 (a) to worship or assemble in connection of a religion or belief and establish and manage places for that purpose ", the letter (c) acquire, create and use adequate equipment and materials necessary with regard to ceremonies or customs a religion or belief ", letter (h) respecting the days of tradition and celebrate holidays and ceremonies in accordance with the teachings of the religion or beliefs", and letter (i) establishing and managing communications with the person and society in matters of religion or belief at the national and international levels ".

13 See Arif Wahyudi, 'Quo Vadis Jaminan Konstitusional Hak Atas Kebebasan Beragama/Berkeyakinan: Menguji Peran Negara,' n.3 2013, Journal of Justice, 4.
Based on the provisions of the Indonesian constitution, the Human Rights Act, UDHR and ICCPR, the right to freedom of religion and belief can be distinguished into two areas, namely internal freedom (forum interum) and external freedom (forum externum) ${ }^{14}$ :

\section{a. Internal Freedom (Forum}

Internum). Internal freedom that provides freedom of conscience to believe, embrace and move religion and belief and the right to maintain or embrace or move from a religion or belief. Rights to freedom have been recognized internationally and nationally as one of the elements of human rights that cannot be reduced and restricted (non derogable rights), even in war and public emergency condition, the state must not intervene nor force (coercion) forum this internum, as stipulated in Article 28 paragraph (1), Article 4 paragraph (2) of the Covenant on Civil and Political Rights and Article 74 and Article 74 of the Human Right Act.

\section{b. External Freedom (Forum}

Externum). Freedom of either alone or together with others, in public or in the private region to manifest religion

\footnotetext{
14 The Wahid Institue (2011), above n.2, 6-10.
} 
or belief in the form of teaching, practice, worship and arrangement. This freedom includes the freedom to establish places of worship, freedom to use religious symbols, the right of freedom to celebrate religious holidays, the right of freedom to elect religious leaders, the right to teach and spread the teachings of religion, the right of parents to educate religion to his son, the right to establish and manage religious organizations.

\section{B. Ambiguity of Freedom of Religion and Belief For Indigenous Peoples}

Interestingly, in many legal provisions regulating the constitutional protection of religious freedom in Indonesia such as constitution, Human Rights Act and other legislation, the government pays more attention on religion than belief/faith. In fact, the number of beliefs that exist in Indonesia exceeds the number of religions officially recognized by the state. According to the Ministry of Culture and Tourism in 2011, the number of believers of nondenominational faiths reached nine million people in 248 center organizations and 980 branches organizations spread across 25 provinces in Indonesia. It means that the government no longer recognizes beliefs as a stand-alone entity beyond religion, yet merely culture. Thus, the legal umbrella is Article 18B paragraph (2) of the 1945 Constitution, stating that "The State recognizes and respects traditional communities along with their traditional customary rights as long as these remain in existence and are in accordance with the societal development and the principles of the Unitary State of the Republic of Indonesia, and shall be regulated by law."

Therefore, there is a conditionality where an entity can be classified as customary law communities, namely; (1) as long as indigenous people exist; (2) in accordance with the times; (3) in accordance with the principles of the Republic of Indonesia; and (4) shall be regulated by law. The existence of this conditionality cause the dependency of indigenous peoples on the political will of the authorities. It can be seen with clause stating "regulated by law". As a result, in case of violation of the constitutional rights pertaining to indigenous peoples' rights including freedom of religion and belief, it will be difficult to get protection from the state. It deals with the status of "recognition" to be provided by law.

According to the provisions of Article 51 (b) of Act Number 24 Year 2003 regarding the Constitutional Court, customary law community can be an applicant in a constitutional case. However, when associated with the prerequisite "recognition regulated by law", the 
customary law community who have not obtained the legality from the state cannot defend their constitutional rights. This then raises a new problem when there is a constitutional violation of the religious freedom of indigenous peoples which cannot be resolved through the legal or constitutional complaint.

Meanwhile in other provisions of Article 28E paragraph (1) and (2) of the 1945 Constitution affirms that the right of religion or belief and worship according to their religion or belief includes in human rights. It is reinforced in the provisions of Article 28 paragraph (1) and (2) of the 1945 Constitution stating that the rights attaching to the right of religious freedom cannot be revoked under any circumstances (non derogable Rights) and the right not to be discriminated against in freedom religion and belief. Human Rights Act also recognizes freedom of diverse and belief as a right that ca not be reduced in any form (non derogable Rights) as defined in Article 4; "The right to life, freedom from torture, the right to personal freedom, freedom of thought and conscience, freedom of religion, .........., are human right that cannot be reduced under any circumstances and by anyone".

However, the provisions mentioned are useless when dealing with Article 28J paragraph (2) of the 1945 Constitution which limits rights guarantees, stating: "In exercising his/her rights and freedoms, every person shall have the duty to accept the restrictions established by law for the sole purposes of guaranteeing the recognition and respect of the rights and freedoms of others and of satisfying just demands based upon considerations of morality, religious values, security and public order in a democratic society."

Meanwhile, the same restriction is also regulated in Article 73 of the Human Rights Act and Article 18 paragraph (3) of the ICCPR. Article 73 of the Human Rights Act, stated: "the rights and freedoms set forth in this law can only be limited by and under the laws, merely to ensure recognition and respect for human rights and fundamental freedoms of others, morality, public order public and national interest ". Article 18 paragraph (3) of the ICCPR, stated: "the freedom to practice religion or beliefs may only be restricted by law are necessary to protect public safety, order, health, or morals or the fundamental rights and freedoms of others".

The limitation provisions mentioned indicated that guarantee that religious freedom which cannot be reduced by anyone and in any form, is limited by the law. This can cause ambiguity for the implementation of the right to religious freedom must be based on the ruling political atmosphere. Related to this, although considered creating ambiguity, 
ICCPR, the Human Rights Act, and the Constitution provide restrictions to the provisions of law are necessary to protect the five elements, namely ${ }^{15}$;

1. Restriction for the Protection of Public Safety. Restrictions on freedom to manifest religion in public can be carried out by the government as in religious meetings, religious processions and funerals in order to protect individual freedom (life, integrity, or health) or ownership. Restriction For The Protection of Public Order. Restrictions on freedom of religion manifests the purpose of maintaining public order, among other legal entities must register religious organizations community, to get permission for holding rallies, establishing places of worship that was common designation.

Restrictions on exercise of religion for inmates.

2. Restriction for the Protection of Public Order. Restrictions on freedom of manifests religion to maintain public order, is exemplified by legal entities must register religious organizations community, to get permission for holding rallies,

${ }^{15}$ See Chandra Setiawan, 'Kebebasan beragama atau Berkeyakinan dan Melaksanakannya ditinjau dari Perspektif HAM', in Komnas Ham journal, Freedom of religion and belief in Indonesia, establishing places of worship that was common designation. Restrictions on exercise of religion for inmates.

3. Restriction for the Protection of Public Health. Restrictions permissible with regard to public health are intended to provide an opportunity for the government to intervene to prevent epidemics or other diseases.

4. Restriction for the Protection of Morals. For the justification of the freedom to manifest religion or belief associated with moral and potentially create controversy.

5. Restriction For The Protection of The (Fundamental) Rights and Freedom of Others.

a. Proselytism. With the penalties for acts of proselytism, the government interfere the freedom of someone in manifesting their religion through missionary activities in order to protect the religious freedom of others so as not to be converted.

b. The government is obliged to restrict manifestations of religion

Jakarta, 2006, 6-7. Also see Arie Wahyudi (2013), above n.14, 4. 
or belief that harm the fundamental rights of others, especially the right to life, liberty, physical integrity of violence, personal, marital, property, health, education, equality, prohibits slavery, cruelty and minority rights.

\section{State intervention against Freedom of religion and belief}

According to a report released by the Wahid Institute in 2015, the actor of violations to religious freedom is still dominated by government. It is not surprising since the trend of government as actor tolerance violations continues to increase year to year. Interestingly, in the regulations to ensure freedom of religion and belief, ICCPR, the Human Rights Act and the Constitution puts the government as an actor who has obligation to protect, respect and fulfill the constitutional rights of the citizens to freedom of religion and belief.

Many problems related to religious freedom in Indonesia includes three large clusters of interrelated to one another. First, problems of law; second, the role of state in law enforcement; and third, an

${ }^{16}$ M. Amin Abdullah, 'Kebabasan Beragama atau Berkeyakinan Dalam Perspektif Kemanusiaan Universal, Agama-agama dan Keindonesiaan', (Paper, presented at the Advanced Training for Lecturers of human rights law and human rights, understanding of nation-states by the society or religions adherers, indigenous people and members of racial or ethnic origin $^{16}$. The government failure to protect the rights of its citizens is the government failure in organizing life of the nation and had breaking the promise of the founding fathers. Meanwhile, one of the state's goals in the opening of UUD 1945 is "to protect the entire Indonesian nation and the entire homeland of Indonesia,....". Some of the government's products of law which tend to be discriminatory and lead to intolerance include:

\section{Application of Act No. 1/PNPS/1965} on the Prevention of Abuse and/or

\section{blasphemy.}

Section 1 of this Act states that religions professed by the nation of Indonesia are Islam, Christian, Protestant, Hindu, Buddhist and Confucius, which subsequently create terms of official and non-official religion. It is obvious that explanation of Article 1 in does not ban different religions or beliefs as Shinto, Jewish, Taoist, wiwitan Sundanese, Javanese, cumin and other communities. However, this acts only recognizes six religions.

cooperation Centre for Human Rights Studies, Islamic University of Indonesia and Norwegian Centre For Human Right, Yogyakarta, 8-10 Juni 2011), 16. 
The polemic against this regulation is primarily on PNPS/1965 as the main umbrella for other regulations related to religion and belief. This law is considered to be contradictive to human rights instruments related to Freedom of Religion and Belief. These contradiction includes ${ }^{17}$ :

a. This law provides space for criminal prosecution against individuals due to their religion or belief. This is contradictive to multiple human rights instruments in which state's obligation is to respect (no intervention) on religion and beliefs embraced by individuals.

b. This law limits the major religions in Indonesia to six religious groups: Islam, Protestant, Catholic, Hindu, Buddha and Confucius although it also acknowledges the existence of religions and beliefs in addition to the six main religions. While human rights instruments recognize the freedom of individuals to profess any religion and belief even not to have a religion (atheist).

c. This law gives privileges to the six recognized religions with the right to receive assistance and protection of the state, while the human rights instruments prohibit discrimination based on religion and belief; and d. This law is considered to be formally and substantively defects. The defect is on the main materials such as religious restrictions set on explanations which later becomes the reference determining religious beliefs, while on Indonesia system of law, the explanation is not a legal norms, rather the official interpretation of laws formation. In addition, this law also raises norm for other laws which is considered unusual in legislation system. The defect also resulted in a legal battle in the regulation of laws giving rise to legal uncertainty. On the other hand, human rights instruments require legal certainty in the context of compliance with human rights obligations.

As a derivative of the Act No. 1/PNPS/1965, there are number of laws related to religion with nearly identical spirit, restricting the freedom of the Indonesian population in terms of religion, some of them are, ${ }^{18}$

a. Minister of Religious Affairs Instruction No. 4 in 1978 on Policy regarding beliefs.

b. Minister of Religious Affairs Instruction No. 14, 1978 on Followup instruction of the Minister of

\footnotetext{
${ }^{17}$ Arief Wahyudi (2013), above n. 14, 10-11.

${ }^{18}$ Siti Musdah Mulia (2008), above n.3, 54-55
} 
Religion No. 4 in 1978 on Policy regarding beliefs.

c. Letter of Minister of Religious Affairs to the Governor of IKDH Level I East Java No. B1/5943178 on Issues Concerning Beliefs.

d. Decree of Attorney General No. Kep. 089/J.A/9/1978 on Prohibition of Marriage Certificate Issued by Center Foundation of Srati Dharma Yogyakarta

e. Letter of the Minister of Home Affair to the Governor of IKDH Level I and the Regent/Mayor throughout Indonesia, no.4771286/1980 on Marriage Registration for believers of God Almighty.

f. Letter of the Attorney General to the Minister of Religious Affairs up. Director General of Islamic Guidance and Hajj Affairs no. B-397D.I.1980 regarding marriage between adherents of Sapto Darmo in Bojonegoro Regional Office.

g. Letter of the Minister of Religious Affairs to the Minister of Home Affair no B.VIl / 59961/1980 regarding Marriage, Identity Cards and the death of the Believers in God Almighty.

h. Decree of the Minister of Home Affairs No. 221a 1975 on
Registration of Marriage and Divorce.

i. Attorney General Decree No.: KEP108/J.A./5/1984 on the establishment of the Coordinating Team for Monitoring Beliefs in Society.

j. Instruction of the Minister of Religious Affairs No. 41978 on Policy Regarding Beliefs.

k. Minister of Religious Affairs Instruction No. 8 of 1979 on Development, Mentoring and Supervision of the organization and beliefs within Islam incompatible with the teachings of Islam.

\section{Act Number 23 of 2006 on Population} Administration

Enactment of Act No. 23 of 2006 on Population Administration with implementing regulations, ie Government Regulations no. 37 of 2007 on the implementation of Act No. 23 of 2006. This regulation was intended to guarantee equality of every citizen in obtaining their rights, including that on the beliefs of minorities.

On the other hand, in citizenship documents there are mechanisms of service process and recording in the Population database of all beliefs, however there is still a distinction between "recognized" and "unrecognized" religions. The provisions of 
Article 8 paragraph (4) stated that implementing agencies implement citizenship Administration with obligation includes specific actions with the "conditions and procedures for Important Event of residents whose religion is not recognized based on the provisions of legislation or for believers based on legislation ".

The phrase about 'non-recognized religion' also appears associated with the religion column in Family Card, who formulating that information concerning religion column for residents whose religion is not recognized as a religion based on the provisions of legislation or for believers is not filled, yet still be served and recorded in citizen database ${ }^{19}$. Similarly, documents associated with ID card, information about the religion for residents whose religion is not recognized as a religion based on the provisions of legislation or for believers is not filled, yet still be served and recorded in citizen database. $^{20}$

The settings in the government regulation can increase the probability of discrimination and make it difficult for the marriage of believers, for example related to the validity of marriages by recording of believers organizations and leaders. Article

\footnotetext{
${ }^{19}$ See Article 61 paragraph (2) of Act No. 23 of 2006
} on Population Administration
81 Regulation No. 37 of 2007, stated: (i) marriages of believers is performed in the presence of believers leaders (ii) believers leaders is elected by the organization to fill out and sign a marriage; and (iii) believers leaders is registered in the ministry whose field and work are technically foster believers of Against God Almighty organization. This means that a marriage is valid only if endorsed by believers leaders who has registered organization.

\section{State Liability In Keeping Freedom Of Religion And Belief In Indonesia}

\section{A. Indonesia Recognizes Sovereignty of God}

The government as a government administrator has an important role in bringing about peace and inter-religious harmony in society. As a sovereign state, the government is entitled to regulate and impose limits on certain things, for example the official state religion. Currently there are six (6) religions officially recognized by the government, namely Islam, Protestantism, Catholicism, Hinduism, Buddhism and Confucianism. In fact, there are some religions and beliefs professed by the community, particularly customary law

\footnotetext{
${ }^{20}$ See Article 64 paragraph (2) of Act No. 23 of 2006 on Population Administration
} 
community, which is not officially recognized by the state.

The inability of the government to give recognition to some religions and beliefs resulted in horizontal conflict in the community. Several other problems also arise due to the lack of recognition of other religions and beliefs, for example related to the religion column in the National Identity Card (KTP), the establishment of religious holidays and alike.

Referring to the concept of sovereignty of God, where the supreme power is considered to be in the hands of God, God is seen as the source of all sources of human power in the world. God is the one who has the authority to regulate and determine everything that exists in the world, even related to beliefs and religions. Human is a technical executor of the will of God. Human, as the executor, not entitled to manage his neighbor including providing regulations on the limits of religion and belief. The idea is almost the same across religions, such as Hinduism, Judaism, Christianity, and Islam. These religions have the same experience in dealing with ideas about the power of the state. God is the one who is first seen as the source of all

21 Jimly Asshiddiqie, Gagasan Kedaulatan Lingkungan: Demokrasi Versus Ekokrasi (online), human power, including in matters of state $^{21}$.

The practice of nation based on God's Sovereignty theory put their country's leaders as the embodiment or manifestation of God. History records that the adherents of the theory of sovereignty of God, making the king as a descendant of the gods (in Hinduism), or caliph as a fiduciary of Allah (in Islam), or the pastor and the rabbi as a trustee or messenger of God (according to Christians and Jews). The impact of this concepts is the inheritance or hereditary between the leaders of the previous king to the next generation. It is commonly known as Theocracy, where that the power of the state, in principle, come from God are embodied in the person of the king or queen for generations ${ }^{22}$. Some countries that use this concept also create restrictions regarding who is eligible to be inducted into the king or leader, for example based on gender (only men were entitled to be a leader) and so on.

Theocracy was initially considered as an ideal concept for a country as it is based on the values of divinity. In its development, however, there is a shift in meaning. The shift is influenced by the nature and character of the king or ruler who

http://www.jimlyasshiddiqie.com accessed on 14 September 2016

22 ibid 
tend to be greedy and do arbitrarily on the basis of religion. God, who gives power to the king, is used as legitimation by the king to conduct his desires. The concept of theocracy lose its adherents when associated with the monarchy, in which there are only certain people are entitled to be a king because of power inherited in the family. In addition, the rise of secularism that tries to separate religion from life of state also becomes one important factor of waning influence of theocracy and the concept of sovereignty of God.

While in the modern era it is rarely found countries implementing purely the concept of sovereignty of God, the basic idea of the concept of sovereignty of God can also be included in other concept of sovereignty such as People's Sovereignty or Sovereignty of Law. The power of God Almighty is still recognized, yet its realization in practice is perceived to be incarnated in the beliefs of every sovereign people. The belief in the omnipotence to God it led to equality in equally sovereign human beings. Every human being is subject only to God and not to man. If a person should be subject to other human beings who occupy status as a leader, then

\footnotetext{
23 ibid

${ }^{24}$ The opening of 1945 constitution and articles in 1945 constitution mentioned two notions of divinities, the first is "Belief in Almighty" and the second "Almighty God". Etymologically, the term "Believe in Almighty" is the equivalent of God's
}

submission can be only acceptable as long as the leaders of precedents in the attitude of obedience to the applicable law, including the provisions of the Almighty ${ }^{23}$.

In Indonesian context, the concept of the sovereignty of God is still relevantly workable and is associated with the idea of Sovereignty of the People and/or the Sovereignty of Law. Constitution of 1945 and Pancasila, placing God as a guide to belief, basically provides guarantees to its citizens to freely embrace religion or belief they believe $i^{24}$. Belief in God Almighty does not discredit certain religions and beliefs as that phrase could be interpreted as universal, not only religion but also belief. The idea and the concept of sovereignty of God in the Indonesian constitution should have guarantees and protects all religions and beliefs embraced by the society. The government should not only recognize particular religions as the state religion. With the restrictions, the idea of the sovereignty of God becomes unclear and prone to trigger conflict. As a sovereign and believes in god state, the government should be able to accommodate all the religions and beliefs of society without exception.

\footnotetext{
sovereignty, or supreme authority in a god, while the term "Almighty God" is very close to understanding godhead in Islam. See Anwar C, Teori dan Hukum Konstitusi, revised edition, Setara Press, Malang, 89.
} 
In practice there is ambiguity and conflict of conception regulations related to the protection, respect and fulfillment of the rights to freedom of religion and belief in Indonesia. First, some regulations confirms that the right to religious freedom is a right that cannot be reduced under any circumstances (non-derogable rights), nondiscrimination and state is responsible in the respect, fulfillment and protection. Second, there are regulations that limit, reduce, and deprive the rights of freedom of religion and belief. Dimensions of human rights law regulations are universal and nondiscriminating. However, there is also a conception that dimension of human rights law is particular and discriminatory ${ }^{25}$. The second conception dimension of human rights law frequently becomes the cause of conflict in society, lead to confusion in the implementation of human rights and is very prone to arbitrary actions (abuse of power) by the power-holders on the basis of human rights.

The universal and non-discriminatory rules are stated in Act No. 39 of 1999 on Human Rights, Act No. 12 of 2005 on Civil and Political Rights and Act No. 29 of 1999 on the Elimination of All Forms of Racial Discrimination. While it is not discriminatory, it is open for the

25 M. Syafi'ie, 'Ambiguitas Hak Kebebasan Beragama di Indonesia dan Posisinya Pasca government to issue a policy that leads to discrimination and intolerance, hence the limitations make its implementation experience ambiguous. On the other hand, the particular and discriminatory rule is Act No. 1/PNPS/1965 on the Prevention of Religious Abuse and Defamation (request for judicial review of the Act was rejected by the Constitutional Court), the Joint Regulation of the Minister of Religious Affairs and the Minister of Home Affair No. 9 of 2006, No. 8 of 2006 on Guidelines of Regional Head Task/Deputy Head of Maintenance of Religious Harmony, Empowerment of Religious Forum and Construction of Houses of Worship, and the application of Article 156A of the Criminal Code related to blasphemy ${ }^{26}$. The refusal of application for judicial review of Law No. 1/PNPS/1965 by the Constitutional Court becomes legal basis related to the legislator's endeavors to clearly limit the freedom of religion and belief in order to maintain public interest.

\section{B. Correlation of the State of Law, Democracy and Religious Freedom in Indonesia}

The Constitution has provided basis that Indonesia is the state of law. The initial

Putusan Mahkamah Konstitusi', Volume 8, Number 5, October 2011, Jurnal Konstitusi, 701 26 ibid 
concept of the state of law was introduced by Plato and Aristotle. Plato stated that the state law is a country that is based on the law and uphold the values of justice for its citizens. Aristotle reinforced the concept with the state main task is to provide opportunity for every individual to live up to the stage of harmony ${ }^{27}$. Certainly, harmony in the life of the nation will not be achieved without law and justice as basis that applies to every citizen. The discourse on the concept of state of law gave birth to the idea that the state of law is a country founded on the rule of law, to ensure justice for every citizen, which aims to achieve harmony of life. For it is based on the law, the act of organizing organ of state must be based on the applicable law, not arbitrariness or authoritarianism.

The birth of the concept of a state of law implies that the ruler acts are restricted by law, and the law should also guarantee the rights of the people through the principle of people sovereignty. The State of law based on the constitution is closely associated with the principle of people sovereignty run through a democratic system. This condition is more evident with the terms of constitutional democracy, the concept of democracy, which is based on the constitution of each country. Therefore,

27 Abdul Aziz Hakim, Negara Hukum dan Demokrasi di Indonesia. (Pustaka Pelajar, Yogyakarta, 2011) law will lose their meaning without democracy, while democracy without rule of law will lose direction ${ }^{28}$. The existence of the state of law in the absence of democratic system that upholds the values of sovereignty will become a tool to limit the rights of individual citizens. Similarly, when democracy is allowed to develop in the absence of clear regulations and rules, chaos will occur in the society. The correlation between the state of law and democracy basically departs from the same background, which is to limit the power of an arbitrary (abuse of power) of the government. Moreover, the purpose of the state of law and democracy are also still in the relevant corridor, which is to guarantee the rights of each individual, creating tranquility, justice and order in the community.

As the state of law that applies the principles of democracy, Indonesia bases its democracy implementation on three sources. First, western socialism that defends the principles of humanism, this principle is also perceived as objective. Second, the teaching of Islam that orders the righteousness of God and justice in society. Third, the pattern of life in the form of collectivism as contained in the villages of Indonesia. The three sources will ensure the

\footnotetext{
${ }^{28}$ Ibid, 160
} 
preservation of democracy in Indonesia that it has strong foundation ${ }^{29}$. Democracy is a term loaded with meaning and interpretation.

This terminology is closely related (Linkage) to social system supporting it. It contains universal elements (common denominator) and contextual content attach to particular social system (cultural relativism $)^{30}$. Democracy will not appear, grow and develop itself in the life of society and nation. It requires real effort of every citizen and supporting devices of wellmaintained culture as a manifestation of mindset and community design. Democratic governance requires democratic culture to make it exist and upright. The democratic culture is the community itself.

Interpreting the identity of real democracy, democratic ideals should substantially embodied in aspects of life of a state including politic, social, and economy. This is consistent with modern democratic political theory popularized by Boron $^{31}$, where democratic model is divided into four levels:

\section{a. Electoral Democracy}

At this level, democracy is characterized by regular elections and

\footnotetext{
${ }^{29}$ Mohammad Hatta, Menuju Negara Hukum, (Idayu Press, Jakarta, 1977), 17

${ }^{30}$ ibid
}

competition among parties to fight for voters. This level of democracy ignores the essence of democracy, and merely indicated to put the elected representatives in the top positions of legislative and executive.

b. Political Democracy

This level is slightly more advanced than the first one through the establishment of political regime to a certain degree, able to appear as effective political representation, purely implement power-sharing, improve the mechanism for people's participation through election (referendum) and popular consultation, strengthen the legislature, create special committees to control executive branch, guarantee the people's right to access information, develop public financing for political campaigns, create institutions that can minimize the role of lobby groups and vested interests. In short, this level can be referred to as a participatory democracy applicable in some parts of Latin America.

c. Social Democracy

This level is a combination of elements attached to the two previous

\footnotetext{
${ }^{31}$ Soebagio, Distorsi dalam Transisi Demokrasi di Indonesia, Vol 13, No 2, December 2009, Makara, Sosial Humaniora, 111-119
} 
democratic levels. It includes social citizenship, broad guarantees on spectrum of the rights of citizens such as living standards, access to education, housing, and medical care.

d. Economic Democracy

The last level is the smoothing of what Lenin called as an economic revolution. For Lenin, politics is economic concentration. In Boron's term, there is no political valued sector than economic. In this sense, political fight or competition are not merely for politics itself, but to win control over limited economic resources. Thus, those who control the economy control politics. This understanding clearly revers the argument of liberal democracy adherents that political territory is separated from that of economy.

Of the four levels, there are some prerequisites to meet to achieve a state of law and the concept of a real democracy. The pre-requisite is evident from interpretation of the state of law and democracy concepts. Democracy is explained in two aspects. First, as a system, democracy is bound by rules (constitution, legislations, and regulations) that have been agreed. Second, as an ideology, democracy is to create

\footnotetext{
${ }^{32}$ Imam Hidayat, Teori-Teori Politik, (Setara Press, Malang, 2012), 86-87.
}

government by concern the people based on ideology. In this aspect, a democratic state should respect the values of Human Rights (HAM) including freedom of thought and expression, freedom of the press, association, freedom of speech, freedom to choose a representative, freedom of politics, freedom of religion and so forth ${ }^{32}$.

Ruslan emphasize the concept of democracy to the fulfillment of human rights to ensure transparency in the system of society, nation and state. Fulfillment and protection guarantee of human rights is a major importance by the state of law and democracy ${ }^{33}$.The elaboration of the state of law and democracy leads to a discourse on the realization of the ideals of limited government power (limited government), the prohibition of arbitrary or authoritarian (abus de draitatau willikeur) acts, the moderate of centralized power, abuse of power or authority (detaournament de pouvair or abuse of power) and the guarantee of human rights ${ }^{34}$.

These ideals will be realized when the government through the institutions of the country comply and obey the existing legal regulations. Moreover, the society should also take a strategic role to support the ideal of the state of law and democracy through

\footnotetext{
33 Ibid

34 Ibid.
} 
direct participation of the activities organized by the government.

Seeing the various statutory provisions discriminating indigenous people in exercising the right to freedom of religion and beliefs, the government, as the stakeholder of rights fulfillment has performed arbitrary power. When this happens, the protection of the citizens, especially minorities, fails. It also indicates that the implementation democracy based on the state of law has failed run by the government. The implementation of nation life is only for group/religion of the majority. Even though the founding father, Soekarno, stated that the first philosophical foundation the proposed to unite all the elements of individuals and groups is the basis of nationality; 35

First of all, I need to ask: Do we want to establish Indonesia State for one person, or certain group? Establish independent Indonesia by name only, yet to glorify one person, to give power to one class of the rich, to give power to aristocratic members? Do we? Of course not! Brothers of nobility and Muslims, all of them have agreed, that is not that kind of country and therefore we have a purpose. We want to establish a state

35 Yudi Latif, Negara Paripurna "Historitas, Rasionalitas, dan Aktualitas Pancasila”, (Gramedia Pustaka Utama, Jakarta, 2011), 331.

36 Majda El Muhtaj, Hak Asasi Manusia dalam Konstitusi Indonesia, (Prenada Media, Jakarta, 2005) of "all for all" ... .We set up a "National State" of Indonesia.

\section{The Government's Role in Ensuring Fulfillment of the Right of Freedom of Religion and Belief}

Amendment of 1945 Constitution is a historical fact and believed to be the starting point of Indonesian democracy empowerment based on human rights protection ${ }^{36}$. Human rights frequently turns into a double-edged knife which sometimes protects humanitarian aspects of human rights yet is very strong with the hegemony of the policy makers. Michael Freeman commented on the discrepancy between the concept of human rights with the reality of human rights violations. He stated; human rights violations are facts than can be, and sometimes are, best expressed in terms of numbers, but there is uneasy relationship between our knowledge of the numbers and our understanding of what they mean. ${ }^{37}$ This is due to two fundamental causes. First, lack of understanding in philosophical content of human rights ${ }^{38}$. Second, the load of human rights substance is also considered to have bias

\footnotetext{
37 Michael Freeman, Human Rights: An Interdisciplinary Approach, (Cambridge Polity Press, Cambridge, 2004), 110

${ }^{38}$ Ibid.
} 
understanding due to the sharp sociopolitical intrigue that surround ${ }^{39}$.

One form of mismatches between concept and practice of human rights in Indonesia is related to the existence of indigenous peoples. The Constitution has guaranteed protection, recognition, and respect for customary law community in Article 18B paragraph (2) and Article 28, first paragraph (3) of the 1945 Constitution. Moreover, several other provisions also guarantee protection, recognition, and respect for customary law community, such as Article 41 of MPR Decree No. TAPXVII/MPR/1998, Article 6 of Act No. 39 of 1999 on Human Rights, Regulation of Ministry of Agrarian/Head of National Land Agency Number 5 of 1999 on Communal Land, Regulation of Minister of Home Affairs No. 37 Year 2007 on the Empowerment and Development of customs, habits of Indigenous Peoples and Institutions in the Region. In addition, the government is still trying to formulate draft of Law of Indigenous People that has been entered in the National Legislation Program since $2004^{40}$.

Of various juridical basis, textual discussion on the protection, recognition, and respect for customary law community

\footnotetext{
${ }^{39}$ Majda El Muhtaj (2005), above n. 37

40 Saafroedin Bahar and Ruswiati Suryasaputra, Arah Politik Hukum Nasional Terhadap Upaya Perlindungan Hukum Bagi Masyarakat [Hukum
}

is still very low and limited to the clauses in the legislation of certain acts. Regulations concerning customary law communities are separated in sector in specific legislation. The majority of the topics raised is with regard to communal land. While other rights of indigenous people such as the right to freedom of religion and belief has not been accommodated by the government in a special regulation. The absence of norms regulating religious beliefs constitutionally has violated the rights of indigenous peoples. For example, Bedouin community in the district of Lebak, Banten, some of whom embraced Sunda Wiwitan religious beliefs. The religious beliefs should be able to be accommodated by the government. The government, through several stakeholders, for example forms Regulation or the Joint Decree (SKB) among ministers.

To accommodate religious beliefs, for example, the government may issue a decree between Ministry of Home Affairs and Ministry of Religious Affairs to provide Religious beliefs column on identity cards. Thus, indigenous people who own particular religious beliefs are not forced to fill it in with religion they do not profess. The phrase of Religious beliefs increases the number of official religions recognized

Adat] Berdasarkan UUD NKRI, Vol 8, Komnas HAM, 2012, Journal of HAM, 14-17 
by the state without adding more number that comes after the official religions. This is because religious belief has covered some of new religions which may appear, for example, Jews, Shiah, Ahmadis and so forth. The logical consequence of this decree is obligation for the Ministry of Religious Affairs to provide facilities for the fulfillment of spiritual service to the Religious Belief. The addition and the recognition of this new religion is aimed at minimizing conflicts among people due to racial issues and a concrete implementation and enforcement function of the state to guarantee the rights of its citizens without exception.

\section{State Liability against Violations of Freedom of Religion and Belief}

Indonesia has provided assurances of protection, recognition, and respect for customary law community in Article 18B (2) and Article 28, first paragraph (3) of the Constitution of 1945. Textually, both the legal basis do not mention the form and other types of protection, recognition, and respect for customary law communities. Therefore, the government is supposed to provide protection, recognition, and respect of the maximum. Maximum means effort and guarantee of protection, recognition, and respect given by the government is not limited to particular sector, for example, only in terms of their customary rights or customary land and so forth. One important aspect that also needs to be given a guarantee of protection, recognition, and respect for indigenous people is related to the freedom of diverse and belief.

Interim report released by The Wahid Institute of the dynamics of religious freedom in Indonesia in 2015, indicated that there were approximately 147 cases of intolerance between religious communities, one of which related beliefs held by indigenous peoples. One of the cases took place in early 2015, April 7 when local religious believers are banned from entering military. The case happened in Banda Aceh openly violated the Constitution and contrary to the Human Rights (HAM). Still in 2015 , there were several organizations that restrict the activities of believers worship. One case occurred in Rembang, Central Java. FUI issued threats to attack Sapta Darma houses of worship. The condition is certainly contrary to the applicable legal basis related to religious freedom and the rule of law related to the guarantee of protection, recognition, and respect for indigenous people.

There is inconsistency shown by the government written rules and its practices, providing opportunities for people to pursue a lawsuit. State, as organizer of nation life, in de facto is unable to perform its role in 
guaranteeing religious freedom for indigenous peoples. On the basis of common interests and reason for creating peace, the government frequently acts arbitrarily and oppresses minorities. The government inability to guarantee protection, recognition, and respect for indigenous peoples can be used as grounds for a lawsuit using the concept of state accountability.

Furthermore, the central and local governments, as state officials, frequently issue regulations creating discrimination for minorities. Local Government, particularly, with the concept as widest possible autonomy frequently issue local regulations of Sharia in plural area, or circular on prohibition of activities for seeker or believers. This can be detrimental to the rights of society. To balance it, mechanism of liability is necessary to anticipate government policy that is harmful as mechanisms to recover it. In civil law countries, such as Indonesia, there are some parameters to use as the foundation for liability ${ }^{41}$ :

\section{Acts;}

41 See Phillipus M. Hadjon, et. al, Hukum Administrasi dan Good Governance, (Trisakti Univerity, Jakarta, 2010), 5.

42 Under Indonesian law, Principles of Good Governance spread across various of laws and regulations such as the act No. 5 of 1086 on the State Administrative Court, Act No. 28 of 1999 on the Implementation of the State A free of corruption, collusion and nepotism, Act No. 25
2. General Principles of law; ${ }^{42}$

3. Human Rights;

4. Good governance; ${ }^{43}$ and

5. Rationality

Qualification in the first parameter to perform a lawsuit against the state in the case of restrictions on freedom of religion and belief has been fulfilled because in Article 18 B (2) and Article 28 I paragraph (3) of the Constitution of 1945, the government has provided a guarantee of protection, recognition, and respect for indigenous peoples. Likewise with other parameters, Restrictions on religious freedom clearly has violated human rights. The government action is also not in accordance with the principles of Good Governance; which according to UNDP includes several parameters, namely: a) participation; b) The rule of law; c) Transparency; d) Responsiveness; e) The common interest; f) The equation; g) Effectiveness and efficiency; $h$ ) Accountability; and i) strategic vision. Thus, people can make claim to the state based on these parameters. State, by looking

of 2009 on public services, Act No. 27 of 2008 on Ombudsman, and Act No. 30 of 2014 on government Administration.

${ }^{43}$ Implementation of good governance with regard to the implementation of a function to organize activities in the public interest, one of which is to ensure the safety of every person and of society. See Ibid, 9. 
at the facts, should have received the lawsuit and provide compensation or remedy for customary law communities whose rights have been restricted by the government.

The next question is how will the lawsuit filed? As mentioned previously, there is ambiguity between laws that guarantee religious freedom for citizens. While the law of "customary law community" has been recognized in the constitution, with prerequisite of "recognition regulated by law", the customary law community who has not obtained the legality from the state cannot defend their constitutional rights. This will certainly make it difficult for indigenous people to defend their constitutional rights before the law either as an applicant or as a plaintiff.

Government, as obligations stakeholder, should use Pancasila as the foundation of philosophy extracted from culture and local wisdom of diverse ethnicities to become adhesive solidarity community of Indonesian life, in social, economic, and political areas through political union of national law.

Indonesian people are familiar with consensus as the value of local wisdom, relying on the wisdom of communitarian "local wisdom" (togetherness). The values of wisdom filled with religious belief of
Indonesian people should be able to be the driving force for the nation's progress and prosperity. The transformation of Pancasila values in public life is expressed by taking into account the dynamic motion of Indonesian people who also face interaction with the world in the current globalization era.

Reflecting on the multiple descriptions of the elaborated case, Indonesian people are actually abundant with many social capitals from different cultures (pluralism and multiculturalism) and religion (Islam as a religion of "majority") has not been able to maximize all the existing potential, particularly against the religion of Islam. As a doctrine with the biggest social capital, it should bear the heavy and noble burden for transforming the values of prophetic ethics in universal life of the Indonesian nation. Therefore the values of universal scaled ethics of Islam are able to reach the whole humanity for the benefit of the Indonesian people. Pancasila as the embodiment of various social capital of culture, religion etc. should be re-used as paradigmatic guidelines in formulating all national development-oriented policies (law). As a result, the achievable progress results is in line soul of our nation's culture, Pancasila. This, of course, should be supported by the 
Brawijaya Law Journal Vol.4 No.1 2017

character of the bureaucrats who have the competence to make it a better nation.

\section{CONCLUSION AND SUGGESTION}

\section{A. Conclusion}

1. The constitutional guarantee of religious freedom for indigenous peoples have been arranged in multiple legislation, both nationally and internationally. However, there are still a lot of discriminations to indigenous people. While human rights has been guaranteed and cannot be reduced in any form and by anyone, the legislation, in fact, limits the freedom that ultimately led to the ambiguity of the implementation of the guarantee of freedom of religion and belief. Ironically, the government is the most frequent perpretator in violations of religious freedom through its intervention in laws, local regulations and policies.

2. The Government has role to guarantee the protection, recognition, and respect for the religious freedom of indigenous peoples. Efforts that can be made by the Government is to create a new norm regarding Religious Belief. Religious Belief will serve as an integral tool for religions beyond the
Constitutional Issues and Indigenous Rights

six official religions recognized previously by the government. This provision also provides juridical implications related to supporting facilities for religious belief, such as the availability of choice of religious belief in identity card, the establishment of Religious Belief Guidance by MORA and so on.

\section{B. Suggestion}

1. The government should be able to accommodate and ensure the fulfillment of the protection, recognition, and respect to religious freedom of indigenous people, through the ratification of the Bill of Indigenous People which also governs the religious freedom of indigenous peoples.

2. The government should establish an institution or official body that regulates the existence, rights and obligations of indigenous communities, such as the National Commission on Indigenous and Tribal Peoples and alike

3. Indigenous and tribal peoples should be more open to the development of globalization that their rights and duties as an entity to be recognized and given in balance. 


\section{REFERENCES}

\section{Journal Articles}

Arief Wahyudi, 'Quo Vadis Jaminan Konstitusional Hak Atas Kebebasan Beragama/Berkeyakinan: Menguji Peran Negara', Third Edition, 2013, Journal of Justice, 1-22

Chandra Setiawan, 'Kebebasan beragama atau Berkeyakinan dan Melaksanakannya ditinjau dari Perspektif HAM', 2006, National Commission of Human Rights Journal, 1-8

M. Syafi'ie, 'Ambiguitas Hak Kebebasan Beragama di Indonesia dan Posisinya Pasca Putusan Mahkamah Konstitusi', Volume 8, Number 5, Oktober, 2011, Constitution Journal, 675-706

Ria Asmi Carsi, 'Inkonsistensi Perlindungan Hukum Bagi Penghayat Kepercayaan Terhadap Tuhan Yang Maha Esa', Third Edition, 2013, Social Justice Journal, 39-40

Saafroedin Bahar and Ruswiati Suryasaputra, 'Arah Politik Hukum Nasional Terhadap Upaya Perlindungan Hukum Bagi Masyarakat [Hukum Adat] Berdasarkan UUD NKRI', Volume
8, 2012, Human Rights Journal, 130

Soebagio, 'Distorsi dalam Transisi Demokrasi di Indonesia', Volume 13, Number 2, Desember 2009Makara Social Humaniora Journal

\section{Book}

Abdul Aziz Hakim, Negara Hukum dan Demokrasi di Indonesia. (Yogjakarta: Pustaka Pelajar 2011)

Anwar C, Teori dan Hukum Konstitusi, edisi revisi (Malang: Setara Press, 2008)

Imam Hidayat, Teori-Teori Politik (Malang: Setara Press, 2012)

Komnas HAM, Upaya Negara Menjamin Hak-Hak Kelompok Minoritas di Indonesia: Sebuah Laporan Awal (Jakarta: Komisi Nasional dan Hak Asasi Manusia, 2016)

Majda El Muhtaj, Hak Asasi Manusia dalam Konstitusi Indonesia (Jakarta: Prenada Media, 2005)

Michael Freeman, Human Rights; An Interdisciplinary Approach, Cambridge: Cambridge Polity Press, 2004)

Mohammad Hatta, Menuju Negara Hukum (Jakarta: Idayu Press, 1997) 
Brawijaya Law Journal Vol.4 No.1 2017

Phillipus M. Hadjon, et. al. Hukum Administrasi dan Good Governance (Jakarta: Univeritas Trisakti, 2010)

The Wahid InstitueLaporan Tahunan Kebebasan

Beragama/Berkeyakinan dan

Intoleransi Tahun 2014 (Jakarta:

The Wahid Institute, 2014)

Yudi Latif, Negara Paripurna: Historitas,

Rasionalitas, dan Aktualitas

Pancasila (Jakarta: Gramedia

Pustaka Utama, 2011)

\section{Conference Paper}

Jimly Asshiddiqie. (2016). Gagasan Kedaulatan Lingkungan:

Demokrasi Versus Ekokrasi, makalah online, available on http://www.jimlyasshiddiqie.com

Lukman Hakim Saefuddin. (2009). Indonesia adalah Negara Agamis: Merumuskan Relasi Agama dan Negara dalam Perspektif Pancasila, Paper for "Kongres Pancasila" held by Gadjah Mada University, Yogyakarta and The Constitutional Court of the Republic of Indonesia, in Yogyakarta, 30 May-1 June 2009

M. Amin Abdullah, 'Kebebasan Beragama Atau Berkeyakinan Dalam Perspektif Kemanusiaan Universal, Agama-Agama Dan Keindonesiaan', (Papers Presented
Constitutional Issues and Indigenous Rights

in forum Advanced Human Rights Training for Lecturers of Law and Human Rights by the Centre for Human Rights Studies, Islamic University of Indonesia (PUSHAM UII) in Yogyakarta in cooperation with Norwegian Centre for Human Rights (NCHR) University of Oslo Norway, Djogjakarta Plaza Hotel, 10 June 2011)

Mahfud MD, ' Kebebasan Beragama Dalam Perspektif Konstitusi', (Paper presented at the Conference of Religious Leaders of ICCPR: Affirming Religious Freedom in Indonesia, Demanding Commitment of President and Vice President-elect, held by Indonesian Conference on Religion and Peace (ICRP) in Vanda II room Wisma Serbaguna, Jakarta, Monday, 5 October 2009)

Siti Musdah Mulia, 'Menuju Kebebasan Beragama', (Paper presented in a Seminar and Workshop of Komnas HAM on the theme of Freedom of Religion and Belief in Indonesia, Palu, 11-12 September 2006)

Siti Musdah Mulia, 'Potret Kebebasan dan Berkeyakinan di Era Reformasi', (Paper presented at the National Workshop on the theme Human Rights Commission of Human 
Rights Enforcement in the 10 Years of Reform, in Borobudur Hotel, Jakarta, 8-11 Juli 2008)

\section{Act}

The Republic of Indonesia. Constitution of the Republic of Indonesia of 1945

The Republic of Indonesia. Act Number 1/PNPS/1965 on the Prevention of Abuse and/or Blasphemy

The Republic of Indonesia. Act Number 39 Year 1999 on Human Rights

The Republic of Indonesia. Act Number 11 of 2005 on Ratification of the International Covenant on the
Rights of Economic, Social and Cultural.

The Republic of Indonesia. Act No. 12 of 2005 on Ratification of the International Covenant on Civil and Political Rights.

The Republic of Indonesia. Act Number 23 of 2006 on Population Administration.

The Republic of Indonesia. Act Number 7 of 2012 on Social Conflict Management.

The Republic of Indonesia. Act Number 30 of 2014 on Governmental Administration. 
